\title{
Analysis of Characteristics of the Southwest Region of Shallow
}

\section{Water Delta}

\author{
Huifang Wang ${ }^{(1)}$, Chuanling Lei(2), Hui Li(1)
}

(Yangtze University College of Technology \& Engineering, Jingzhou，434020, China ${ }^{\circledR}$;

The First Oil Production Plant of Dagang Oilfield, CNPC, Tianjin, 300280, China ${ }^{(1)}$

Key words: southwestern Qaidam Basin; shallow water delta; forming conditions

Abstract: The southwest region of Qaidam, in the sedimentary period in Paleogene, with relatively flat structure and basal stability evenly subsidence, was formed the " broad and shallow lake basin " ancient terrain. Ancient climate is arid or semi-arid environment, and such climate caused the intense physical weathering in source rock. The ancient water is shallow, less than $10 \mathrm{~m}$, and lake level fluctuation is frequent, with lake level cycle variation. Terrigenous detrital material in flat structure basin was carried for a long distance by large rivers, which provided forming conditions for a large shallow water delta. The southwest region in Paleogene mainly exists in the five source supply directions, such as the provenance of the Altyn mountain, Tiemulike, Qimantag Mountains, east Chai mountain. According to the relationship of lake basin climate changing and the lake level changes, the form of the shallow water delta sand body can be classified into three types, sheet, lump and branch shape.

Shallow water delta is a kind of delta that is developed in stable shallow water and construction, such as the tableland, the continental sea or flat terrain, the integral secular subsiding depression basin $^{[1-4]}$. The main characteristics of shallow water delta can be summarized from three aspects, forming conditions, sedimentary characteristics and distribution of sandbody. And this type of delta is often formed in the basement, wide basin slope stability subsidence ease the ancient water shallow geological background conditions. Sedimentary characteristics are fine lithology, medium maturity, traction current characteristics with rich strong hydrodynamic sedimentary structure, biological disturbance strongly, development in distributary channel sand body, thin and wide and superimposed, which is an important goal of lithologic reservoir exploration ${ }^{[5-10]}$. At present, the classification of the shallow water delta mainly has two solutions: the first is based primarily on the size of delta front tilt of the slope, namely whether the developmental Gilbert three layer structure as the standard, such as Postma divided into 2 subclasses, traditional and mouth bar, 8 kinds of shallow water delta and introduce for the source system (alluvial fan, braided stream, meandering river), the carpet type and Gilbert type two subclasses, and 6 types of shallow water delta ${ }^{[11]}$. Another classification scheme is based on development of shallow water delta sand body form standard, and mainly can be divided into three subclassed: sheet, lump and dendritic, and corresponding to the lake basin lake level changes at different times. Since 1980s, domestic scholars had developed the study of shallow water delta, including sedimentary characteristics, facies, sand body and distribution of favorable reservoir and lithologic trap accumulation regularity, mainly in the Songliao basin ${ }^{[12]}$, Ordos basin ${ }^{[11,13]}$, Bohai bay basin ${ }^{[14-15]}$ and the Sichuan basin ${ }^{[16]}$ etc. major 
oil and gas basin of shallow water delta. Because of shallow water delta development background, the dynamic mechanism and sedimentary facies belt combination control of many factors, there are still some disputes on some issues, such as shallow water delta formation and coupling relationship of basin tectonic evolution, definition of shallow water delta formed the ancient water depth and the degree of development of estuary dam. Southwest Qaidam basin mainly developed the front of the alluvial fan, fan delta sedimentary system and the Qi diffuse tager piedmont Aral river braided river, delta, littoral and shallow lake sedimentary system ${ }^{[17]}$. Changmin Zhang ${ }^{[18]}$, dissected the sand body using the data of dense well pattern in Paleogene and Neogene in Yuejin region, finding that the development of the delta sedimentary system in southwest wood belongs to a shallow water lake delta, different structural parts in the same period has two completely different form of the distribution of sand body on the plate which is characterized by continuous distribution of sand body, and the sand body of footwall is relatively limited narrow strip of sand body distribution. Although the predecessors have been put forward the development of the southwest area of shallow water delta, systematic development of the southwest area of shallow water delta ancient geographical environment and the study of sedimentary characteristics is imperfect, the author aims at the problems, combined with the regional geological, geophysical data and laboratory analysis data, the sedimentary period of the ancient landform in Paleogene, and makes a comprehensive analysis of ancient climate and the depth of the water, establishing strike-slip extrusion type depression basin in the shallow water delta sand control mode, the southwest area in order to provide theoretical basis for the exploration of lithology reservoir.

\section{Regional geological background}

Southwest area in Qaidam basin is between the Arjin mountain and the Qimantag Mountains in the southwest, and northeast fracture is bounded by XI, east to east Qaidam, and the area is $7500 \mathrm{~km}^{2}$, which is a development of Cenozoic foreland depression zone (figure 1). Oil and gas resources is the southwest area of Qaidam basin is found that the highest in most oilfields, reserves abundance, and by the end of 2009 , the area's proven reserves of oil and gas are about $2.77 \times 10^{8}$ ton, proven rate is only $22 \%$, and the lithologic reservoir exploration potential is large. The Cenozoic strata development is complete, from bottom to up are Palaeogene Lulehe group $\left(\mathrm{E}_{1+2}\right)$, the lower Ganchaigou formation $\left(\mathrm{E}_{3}{ }^{1}\right)$ and lower Ganchaigou formation $\left(\mathrm{E}_{3}{ }^{2}\right)$, upper Ganchaigou formation in the upper $\left(\mathrm{N}_{1}\right)$, Neogene of oil sands mountain group $\left(\mathrm{N}_{2}{ }^{1}\right)$, oil sands on the mountain $\left(\mathrm{N}_{2}{ }^{2}\right)$, the lion ditch group $\left(\mathrm{N}_{2}{ }^{3}\right)$, Quaternary Qigequan group $\left(\mathrm{Q}_{3+4}\right)$, the main exploration target strata for road le river group (Paleocene, Eocene early, $54 \sim 44 \mathrm{Ma}$ ), the lower Ganchaigou formation (in the Eocene, $44 \sim 38 \mathrm{Ma}$ ), upper Ganchaigou formation (late Eocene, Oligocene, $31 \sim 22 \mathrm{Ma}$ ) and the oil sands mountain group (early middle Miocene, $22 \sim 15 \mathrm{Ma})^{[19]}$. 


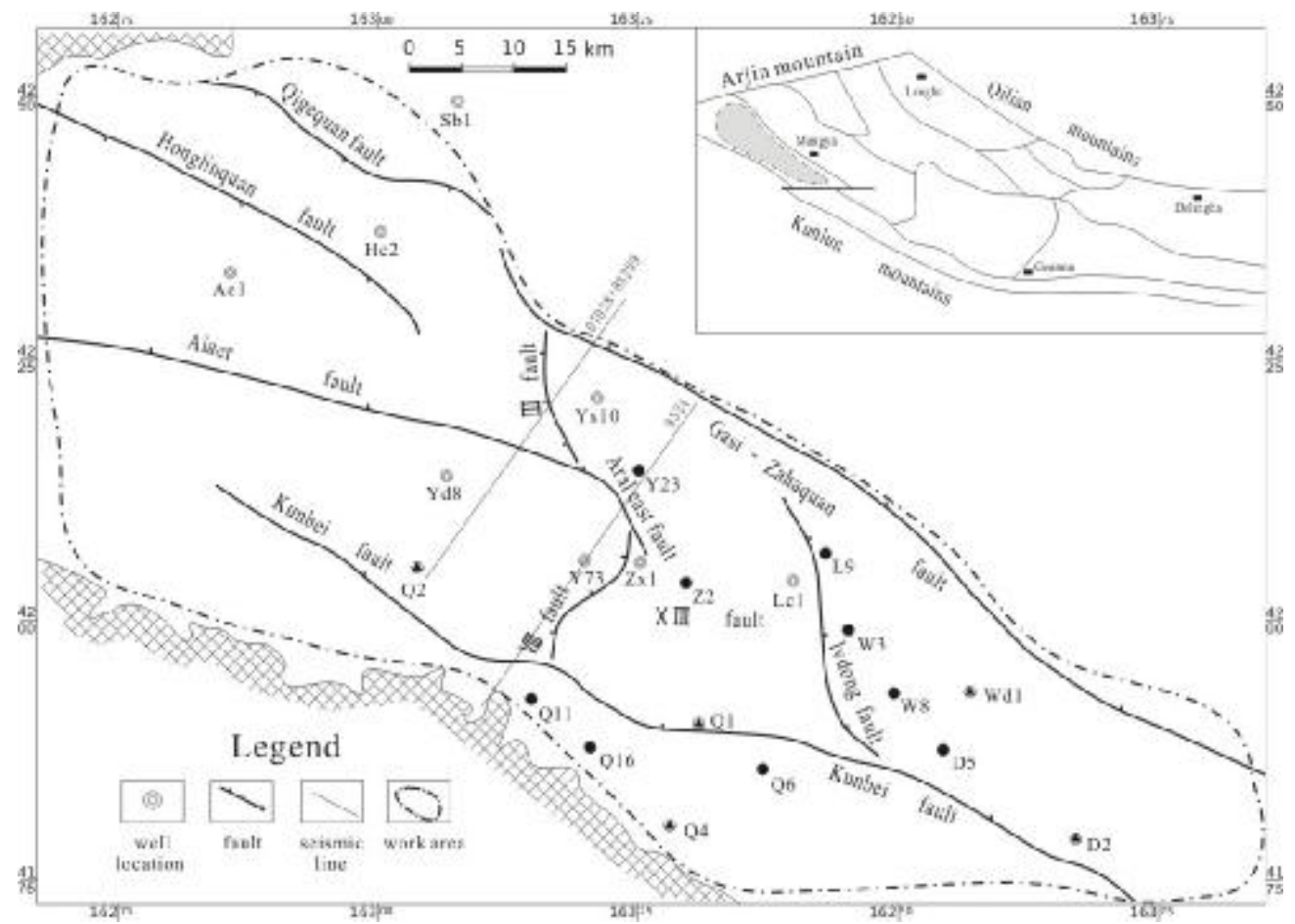

Fig. 1 Map of tectonic divisions and main faults in southwest Qaidam Basin

Structure in western Qaidam basin is very complex, controlled by Kunlun mountains in the southern margin of the basin and Qitager mountain thrust fault system and the northwest of Alkin sinistral strike-slip fault from Paleogenein, thus forming 2 faulted frameworks: the NWW and NEE. Western Qaidam basin is divided into four secondary tectonic zones by the 2 faulted frameworks, Kunbei fault, Essential - zahaquan fault fold structural belt, hero ridge slippage fault fold structural belt and the central depression belt. Kunbei fault structure zone and Essential - zaha springs fault fold structural belt formed the main body of southwest of Qaidam ${ }^{[20]}$, including Kunbei fault, the Aral fault (including the Aral east fault), Hongliuqun fault, XI fault, III fault, Lvdong fault and XIII fault.

\section{Shallow water delta development background}

the southwest of Qaidam area in Paleogene can develop a large shallow water delta deposits, mainly because the regional tectonic flat basin and shallow lake sedimentary period, and the paleo-water-depth is very shallow, and dry heat source of the ancient climate with plenty of sediment supply.

\section{Ancient tectonic setting}

Since the Jurassic period, Qaidam basin have entered into a state of extrusion, until today. the southwest of Qaidam area under the system of the compressional stress for a long time from Cenozoic. Evolution can be divided into bending depression $\left(E_{1+2}\right.$ early to late $\left.N_{1}\right)$, thrust $\left(\mathrm{N}_{2}{ }^{1}\right)$, strong thrust $\left(\mathrm{N}_{2}{ }^{2}\right.$ early $\sim \mathrm{N}_{2}{ }^{3}$ late) and surface decollement fold (Q) four major tectonic evolution stages. Flexure depression stage is a stable sedimentary environment, with sedimentary scope broad, may over the Altun mountain, and develops low amplitude uplift only in some area ${ }^{[21]}$. Through to the ancient terrain seven springs slope recovery results found that the ancient slope in the Mesozoic period is high in southeast and northwest low, flat in Paleogene, and Neogene then shows high is northwest, southeast low tectonic framework ${ }^{[22]}$.

A large number of structural balance section also indicated that the southwest in Qaidam region in the sedimentary period in Paleogene was relatively flat structure, basal stability evenly subsidence, 
flat, and stratigraphic occurrence was close to level, not much change the thickness of strata (figure 2). Thus, the southwest in Qaidam area in Paleogene, has basin and shallow lake rich ancient terrain, and formed in the large shallow water delta paleostructural basis.
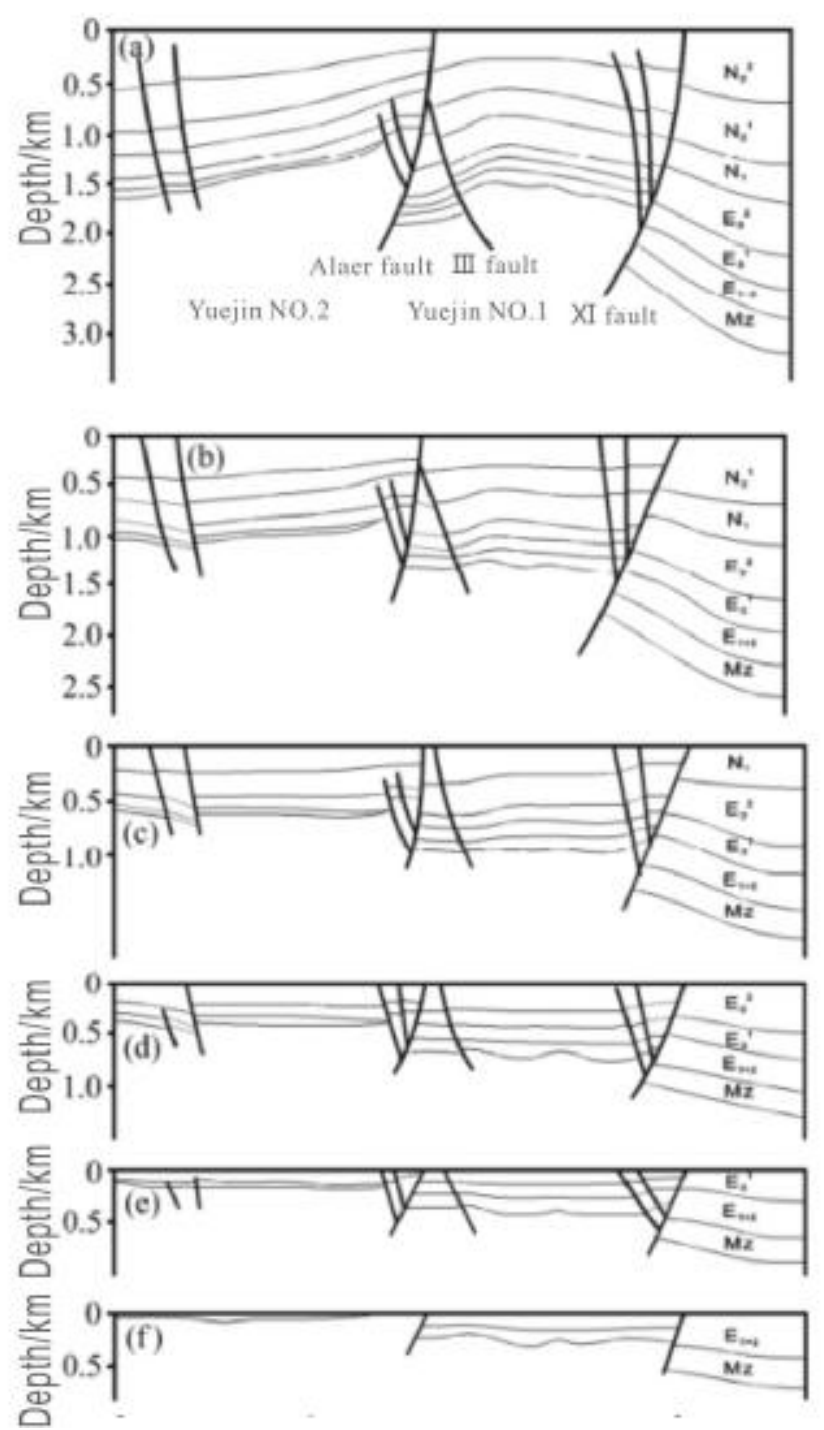

(a)the end of $\mathrm{N}_{3}{ }^{2}$; (b)the end of $\mathrm{N}_{2}{ }^{1}$; (c)the end of $\mathrm{N}_{1}$ (d)the end of $E_{3}^{2}$; (e)the end of $E_{2}^{1}$; (f)the end of $E_{1+2}$

Fig. 2 Balance cross sections of line $\mathrm{AA}^{\prime}$ in southwest

Qaidam Basin

\section{Ancient climate background}

According to of the Qaidam basin in lacustrine facies sedimentary carbon and oxygen isotope analysis $^{[23]}$, the basin during Oligocene uplifted to an altitude of about $2500 \mathrm{~m}$, and the annual temperature was $20^{\circ} \mathrm{C}$. Through the analysis of a large number of micro fossils, In Qaidam basin during the Paleocene to Eocene palynoflora was mainly angiosperms, containing a large number of neem powder belongs to Meliaceoidites, oak powder Qoercoidites, white powder Nitrariadites etc, and ephedra powder Epheddripites is the largest number of gymnosperms, which was on behalf of 
the warm hot semi-arid climate, altitude of about $500 \mathrm{~m}$. Early Oligocene has a lot of reflection of semi-arid forest and scrub vegetation sporopollen, vegetation for brush type, and in mid late is scrub and grassland and the situation of mixed, to indicate Oligocene basin is $1000 \sim 1500 \mathrm{~m}$ altitude, ancient temperatures for drought conditions. Through of the basin in reefs paleontological identification, isotope test and geochemical data were analyzed, and Qaidam basin in organic reef development period (mainly $\mathrm{E}_{3}{ }^{2}$ and $\mathrm{N}_{1}$ ), geographic location may be located in north latitude $30^{\circ}$ tropical, subtropical region, south of under $1500 \mathrm{~m}$ altitude. The ancient climate characterized is warm and dry, and sedimentary environment is salt water - brackish water of inland salt lake ${ }^{[24]}$.

In the southwest area, a comprehensive analysis of the ancient sedimentary period in ancient climate is arid or semi-arid environment, the climate caused the source rock of intense physical weathering. Terrigenous clastic materials was transported for a long-distance by large rivers in relatively flat structure basin, which providing a rich material foundation for the formation of a large shallow water delta.

\section{The background of the water body}

In the middle of the lake basin, the wind effect directly forms the strong waves in the lake water, and water fluctuation caused by $1 / 2$ wavelength wave amplitude to lake water depth, water particle almost no movement, the depth of the depth of interface is called the wave base. The following basic is not affected by the lake wave, to be a static water environment. According to the research on modern lake waves on the surface of the base, the wave base depth is less than $20 \mathrm{~m}$, so shore shallow lake area above the wave base is identified as the shallow water by Caineng Zou etc. .

Creatures in Paleogene strata in the western Qaidam basin sequence are respectively lower Ganchaigou formation under the south star interfaces - MeiQiu chara combination on the belt and lower Ganchaigou formation period of multilateral true star interfaces - pointed Mihoshi interface chai north ditch the combination with interface. South star interfaces Austrocypris mainly distributed in lake invasion systems tract (TST), the general life in the small estuary, lake and water have different degree of salty function, reflect the ancient climate dry environment. True star interfaces (Eucypris) fossil is indicated by the background, and there is a salinity of sedimentary environment of liquidity to shallow water, and may be associated with delta plain marsh beach environment, usually in high domain (HST) at the top. Chara ecological generally produced water into the domain (TST) and high field (HST), suitable for fresh water and relatively quiet water ${ }^{[25]}$. Su Xin etc. ${ }^{[26]}$ adopt microbody paleontology on sedimentary rock in Dongying sag and the early ancient lake water depth for quantitative analysis, and think south star interfaces may reflect, the ancient water depth is $4 \sim 10 \mathrm{~m}$, stonewort is between $0 \sim 5 \mathrm{~m}$. Thus, whether to judge from the ancient water depth qualitative or quantitative analysis of the ancient water depth, delta sedimentary period in Paleogene sedimentary the southwest area of the ancient water depth generally remains at around $10 \mathrm{~m}$, in a typical shallow sedimentary environment.

Predecessors used to a detailed analysis of magnetic susceptibility data in western Qaidam basin ${ }^{[27]}$, found that the upper and lower Ganchaigou formation $\left(\mathrm{E}_{3}{ }^{1}\right.$ to $\left.\mathrm{N}_{1}\right)$ formation from old to new, a total of 161 different thickness of sedimentary cycle, and cycle thickness distribution between $2.3 \sim 2.3 \mathrm{~m}$, while by natural gamma ray data cycle analysis, calculating 454 depositional cycles, thickness of $2.5 \sim 2.5 \mathrm{~m}$, the comprehensive comparison of frequency spectrum analysis showed that upper and lower Ganchaigou formation main relative lake level change cycle thickness of $2 \sim 4 \mathrm{~m}$ and $5 \sim 10$ $\mathrm{m}$, illustrating the southwest region in the relative lake level change quite frequently in Paleogene, water turbulence back and forth, fully reflect the characteristics of shallow water sedimentary environment. 


\section{Shallow water delta sand body}

the southwest of Qaidam area in Paleogene Mainly exists in the front provenance of Altun mountain, the aral source, iron wood rick source, Diffuse tager mountain source and east Chai hill five source provenance supply directions ${ }^{[17]}$. According to the source distance, ancient topography and sediment characteristics, the Altun mountain source area can be divided into proximal steep slope sedimentary system, development of alluvial fan, fan delta, nearshore subaqueous fan, lake sedimentary system, which mainly distribut in the seven springs area, and other source area is far source gentle slope type depositional systems, in braided river, braided river delta, lake sedimentary system characterized (table 1), which is the main sedimentary system in the study area. Shallow water delta also has the following the southwest area of shallow water delta sedimentary common characteristics: 1) Gilbert type top horizon, foreset, bottom product of 3 layers structure development is not obvious, the lack of progradation seismic reflection structure; 2) mainly underwater distributary channel sand body, sand body with different degree of sheet, and the vertical sedimentary sequence is usually discontinuous; 3) shallow lacustrine shale, a former delta deposits.

Table 1 Characteristics of Paleogene shallow delta mirco-facies in southwestern Qaidam Basi

\begin{tabular}{|c|c|c|c|c|c|}
\hline $\begin{array}{l}\text { sedimenta } \\
\text { ry facies }\end{array}$ & $\begin{array}{l}\text { subfaci } \\
\text { es }\end{array}$ & microfacies & sedimentary character & bedding structure & curve shape \\
\hline \multirow[t]{5}{*}{$\begin{array}{l}\text { braided } \\
\text { river-delta }\end{array}$} & $\begin{array}{l}\text { delta } \\
\text { front }\end{array}$ & $\begin{array}{l}\text { distributary } \\
\text { channel }\end{array}$ & $\begin{array}{l}\text { brown glutenite, } \\
\text { psephitic sandstone, } \\
\text { pebbled sandstone, } \\
\text { inequigranular sandstone }\end{array}$ & $\begin{array}{l}\text { cross-bedding, } \\
\text { graded bedding }\end{array}$ & high box \\
\hline & & $\begin{array}{l}\text { distributary } \\
\text { interchannel }\end{array}$ & $\begin{array}{l}\text { brown mudstone,silty } \\
\text { mudstone, intercalated } \\
\text { with siltstone, packsand }\end{array}$ & $\begin{array}{l}\text { horizontal } \\
\text { bedding, } \\
\text { deformed } \\
\text { bedding, plant } \\
\text { root }\end{array}$ & $\begin{array}{l}\text { low } \\
\text { dentation }\end{array}$ \\
\hline & $\begin{array}{l}\text { delta } \\
\text { plain }\end{array}$ & $\begin{array}{l}\text { underwater } \\
\text { distributary } \\
\text { channel }\end{array}$ & $\begin{array}{l}\text { Brown, brown-gray } \\
\text { glutenite,psephitic } \\
\text { sandstone, } \\
\text { medium-coarse sandstone }\end{array}$ & $\begin{array}{l}\text { cross-bedding, } \\
\text { inclined bedding, } \\
\text { scour structure }\end{array}$ & $\begin{array}{l}\text { Campanifor } \\
\text { mbox }\end{array}$ \\
\hline & & $\begin{array}{l}\text { underwater } \\
\text { distributary } \\
\text { interchannel }\end{array}$ & $\begin{array}{l}\text { Taupe, brown, } \\
\text { brown-grey mudstone, } \\
\text { silty mudstone or } \\
\text { pelitic siltstone }\end{array}$ & $\begin{array}{l}\text { horizontal } \\
\text { bedding, } \\
\text { deformed } \\
\text { bedding, } \\
\text { bioturbation }\end{array}$ & $\begin{array}{l}\text { fair } \\
\text { dentation }\end{array}$ \\
\hline & & sand sheet & $\begin{array}{l}\text { brown-gray thin } \\
\text { packsand, siltstone }\end{array}$ & $\begin{array}{l}\text { horizontal } \\
\text { bedding, } \\
\text { deformed } \\
\text { bedding }\end{array}$ & $\begin{array}{l}\text { low } \\
\text { campanifor } \\
\mathrm{m}\end{array}$ \\
\hline
\end{tabular}

\section{Sand body lithology}

Shallow water of braided river delta is the most development in the study area in Paleogene, and delta front subfacies is the body of the delta facies. The lithology in shallow water delta is chiefly mid-fine sandstone, siltstone, conglomerate and gravel sandstone with palm red shale (figure 3). 
According to the analysis of sandstone rock mineral composition, quartz particle mass fraction is $15 \% \sim 45 \%$, mass fraction is $10 \% \sim 43 \%$, and feldspar lithic mass fraction is $30 \% \sim 70 \%$, the main rock types for feldspar lithic sandstone and lithic feldspar sandstone., the structure of Sandstone is the medium maturity, mudstone matrix is generally less than $3 \%$, and the separation is medium.

Ancient water of the study area in Paleogene is shallow and unrest, with the rich reflects the strong hydrodynamic formation sedimentary structure and biological trace fossils. The core in Hongliuquan area in lower Ganchaigou formation $\left(\mathrm{E}_{3}{ }^{1}\right)$ can find the small groove cross-bedding (figure 4 (a)), wedge cross-bedding (figure 4 (b)); uneven wash surface sedimentary structure (figure 4 (c)) and directional amaranth boulder (figure 4 (d)) are developed in the underwater distributary channel microfacies. At the same time, the lower Ganchaigou formation $\left(\mathrm{E}_{3}{ }^{1}\right)$ also holds a small amount of "oxidation root molds form" fragments of the plant roots (figure 4 (e)), the strong biological disturbance can also be observed in some sections, living in a vertical or inclined,

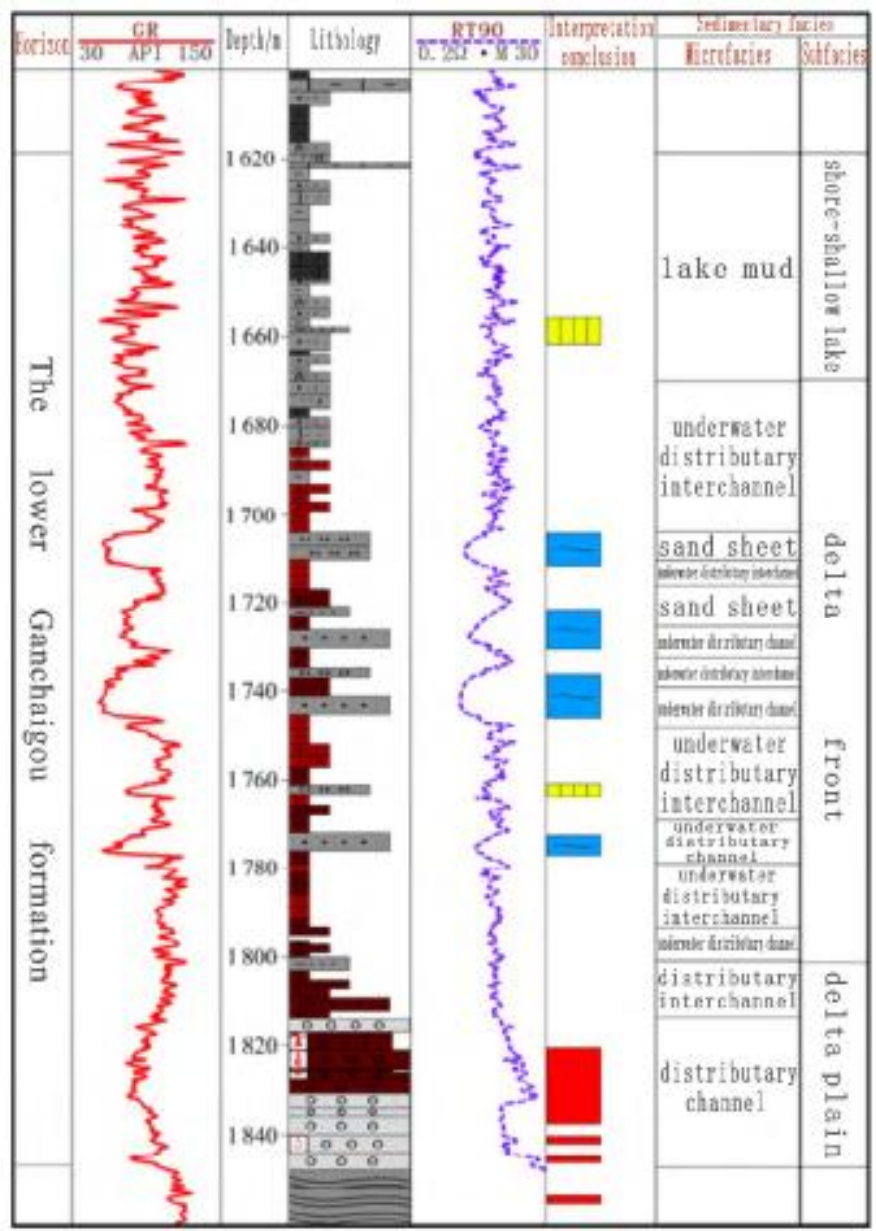

foraging burrow systems (figure 4 (f)).

Fig. 3 Sedimentary columnar section of $\mathrm{E}_{3}{ }^{1}$, Q12 well in southwestern Qaidam Basin

\section{Sand body shape}

Shallow water delta sand body shape is controlled by many combined factors. And the most important influence factors should be the climate. In dry conditions, with reduced precipitation, evaporation, water gradually becomes shallow lake basin, provenance supply relative lack, underwater distributary channel in the coastal area of wave and flow under the action of long-term washout, reflux, sheet sand body was highly, easy to form a generally positive rhythm of the continuous sand body, to be the plane sheet form. In damp or half under drought condition, the 
increase of precipitation, evaporation, lake basin water becomes darker, and provenance supply is adequate, underwater distributary channel after filling deposit by wave and shore current scour renovation for a long time, sheet sand body of the level is lower, the sand body of dendritic morphology, pushed to the center of lake basin. The another more important influence factor of sand body form is the change of the relative lake level, and lake level from relatively slow rises to relatively stable, until the lake level the whole lift cycle of falling fast, causing the ancient water from shallow to deep and shallow, rehabilitation of sand body through a process of change from strong to weak to strong.

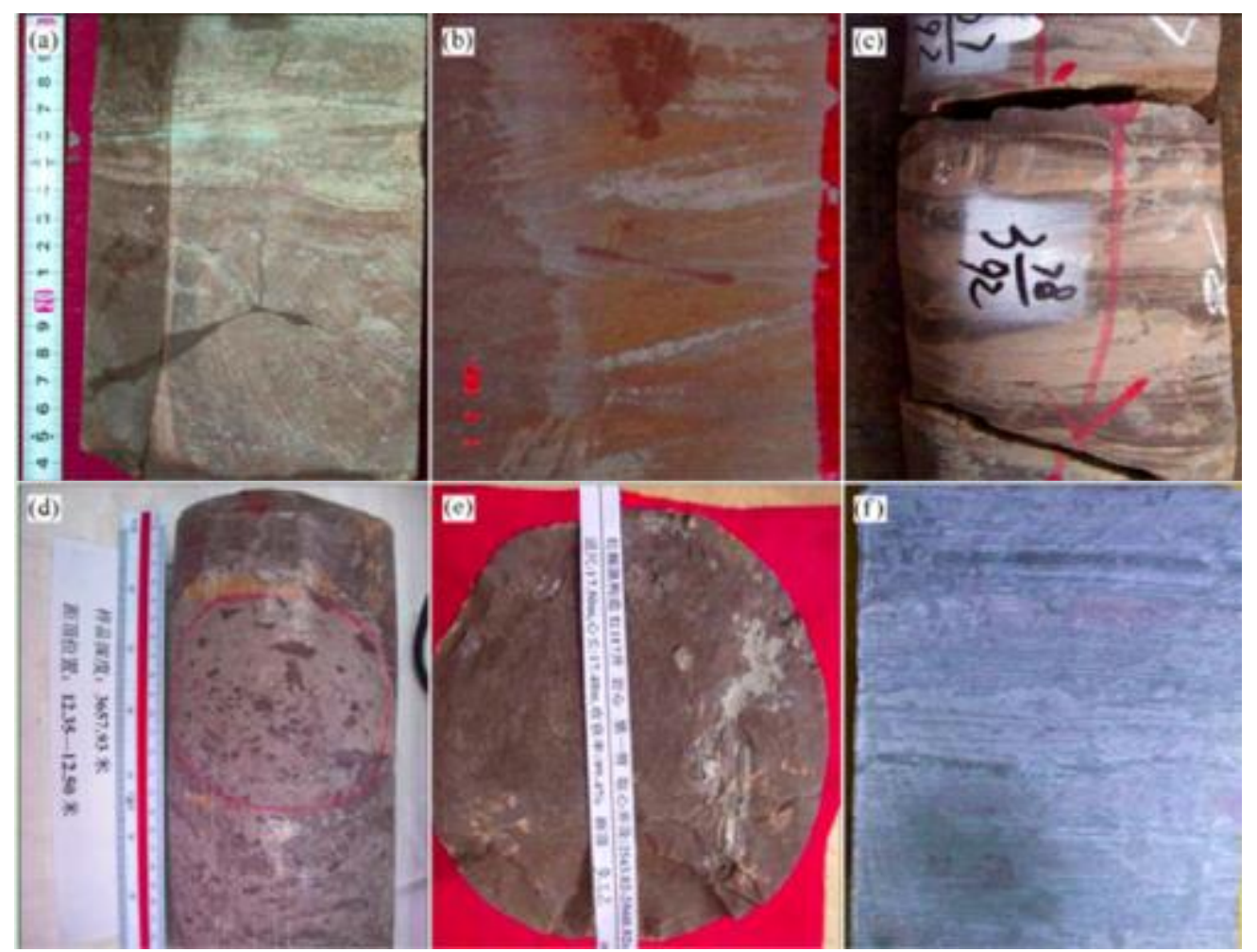

Fig. 4. (a)festoon cross-bedding, H18 well, 2715.00 2715.05m, pebbled siltstone; (b)wedge cross-bedding, $\mathrm{H} 37$ well,1510.00, $\mathrm{E}_{3}{ }^{1}$,red-brown sandstone; (c)erodsion surface, H117 well,2591.00 2591.50m, $\mathrm{E}_{3}{ }^{1}$, crimson mudstone intercalated by grey fine sandstone; (d)boulder clay lineation, $\mathrm{H} 119,3653.93 \mathrm{~m}, \mathrm{E}_{3}{ }^{1}$, lower grey pebbled siltstone; upper crimson mudstone; (e)phytoclasts,H117 well,2602.24m, $\mathrm{E}_{3}{ }^{1}$, crimson mudstone; (f)bioturbation structure, vein structure, $\mathrm{H} 117$ well, $2649.50 \mathrm{~m}, \mathrm{E}_{3}{ }^{1}$, laurel green gray argillaceous siltstoue.

Fig. 4 Typical sedimentary structures of shallow delta of Paleogene in southwestern Qaidam Basin Therefore, according to the lake basin climate change and the coupling relationship with the lake level changes, the form of the shallow water delta sand body can be classified into sheet, lump and dendritic three types (table 2). Southwest area of Qaidam in combination with the ancient tectonic and paleoclimate evolution characteristics, we think that the study area in lower Ganchaigou formation $\left(\mathrm{E}_{3}{ }^{1}\right)$ sedimentary period, save the backbone fracture to activate, but activity intensity is small, the lake basin stable sinks to accept deposits, relative lake level slowly rising. At the same time, the ancient climate shifts from arid to semiarid, terrigenous fragment are plentifully supplied, and the water becomes darker, the delta plain distributary channel go fast into the lake basin, wave and flow along the underwater distributary channel sand body modification get weak, sand body presents the dendritic constantly advancing lake basin center, form a "great plains small front" shallow water delta form (figure 5 (a)). In Ganchaigou formation $\left(\mathrm{E}_{3}{ }^{2}\right)$ in the upper sedimentary 
period, due to the strong uplift of Qinghai-Tibet plateau, the deformation of the southwest region intensity reached the highest peak in Paleogene, and palaeoclimate is relative humidity, causing expansion of lake basin, the water depth to maximize, sand body in the process of advancing lake basin is hampered by the lake effect strengthen gradually, forming medium size and shall lump shape of sand body (figure 5(b)). In Ganchaigou formation $\left(\mathrm{N}_{1}\right)$ sedimentary period, the intensity of tectonic movement began to abate, at the same time, lake basin gradually atrophic, ancient from semi-arid to arid climate change, the source of supply began to decrease, the depth of the ancient water becomes shallow, sand body in the process of advancing lake basin center by lake wave and long shore current strong reform, and the level sheet is very high, the formation of composite covered a wide range of sand body (figure 5 (c)).

Table 2 Sandstones shape classification table of shallow delta in southwestern Qaidam Basin

\begin{tabular}{|c|c|c|c|c|c|c|}
\hline $\begin{array}{l}\text { climate } \\
\text { change }\end{array}$ & $\begin{array}{l}\text { relative } \\
\text { lake level }\end{array}$ & $\begin{array}{l}\text { level of } \\
\text { sheetlizati } \\
\text { on }\end{array}$ & $\begin{array}{l}\text { provenan } \\
\text { ce supply }\end{array}$ & $\begin{array}{l}\text { sand } \\
\text { body } \\
\text { morpholo } \\
\text { gy }\end{array}$ & characteristics of sand body & $\begin{array}{l}\text { Correspondi } \\
\text { ng horizon }\end{array}$ \\
\hline $\begin{array}{l}\text { semiarid } \\
\text { to arid }\end{array}$ & $\begin{array}{l}\text { lake level } \\
\text { falling } \\
\text { fast }\end{array}$ & high & $\begin{array}{l}\text { relative } \\
\text { not } \\
\text { enough }\end{array}$ & sheet & $\begin{array}{l}\text { The delta plain is narrow, the } \\
\text { delta front is broad, sandbodys } \\
\text { overlay eachother and are } \\
\text { continuous. Sand body } \\
\text { distribution of delta parallel } \\
\text { lakestrandline, small single layer } \\
\text { thickness. the parasequence } \\
\text { mainly consists of positive } \\
\text { rhythm }\end{array}$ & $\mathrm{N}_{1}$ \\
\hline semiarid & $\begin{array}{l}\text { lake level } \\
\text { relatively } \\
\text { stable }\end{array}$ & $\begin{array}{l}\text { medium-hi } \\
\text { gh }\end{array}$ & $\begin{array}{l}\text { relative } \\
\text { enough }\end{array}$ & cuspate & $\begin{array}{l}\text { The plain and front of delta } \\
\text { distribution are equel, single } \\
\text { layer thickness and scale are } \\
\text { medium }\end{array}$ & $\mathrm{E}_{3}^{2}$ \\
\hline $\begin{array}{l}\text { arid to } \\
\text { semiarid }\end{array}$ & $\begin{array}{l}\text { lake level } \\
\text { slow } \\
\text { rising }\end{array}$ & medium & $\begin{array}{l}\text { relative } \\
\text { enough }\end{array}$ & dendrite & $\begin{array}{l}\text { The delta plain is broad,the delta } \\
\text { front is narrow, isolated } \\
\text { sandbodys . Sand body } \\
\text { distribution of delta are } \\
\text { perpendicular to lakestrandline, } \\
\text { big small single layer thickness }\end{array}$ & $\mathrm{E}_{3}{ }^{1}$ \\
\hline
\end{tabular}

\section{Shallow water delta sand body distributed regularity}

The distribution of shallow water delta sand body in open flow depression lake basin center is controlled by the open circulation way or the overflow channel, and lake basin center sand body extend in the direction of spillway. Shallow water delta sand body distribution is also controlled by the lake level and source direction. Yuanhao Li etc. ${ }^{[13]}$ made a study in the northwest of Ordos basin, Triassic Yanchang group Chang 8 period of reservoir group of shallow water delta sand body and found that sand body distribution direction mainly controlled by the direction of river, developing cuspate sand along the channel, and these cuspate sand bodies distribute near the lake shoreline, like a ring belt around the basin, and then puts forward the "lake shoreline control sand". In short, 
shallow water delta sand body distribution is mainly affected by the antiquities source, ancient landform, water depth, and the comprehensive control, as previously mentioned, paleo-provenance and ancient southwest area water depth control the shape and size of the shallow water delta sand body (table 2), and the ancient landform is mainly controlled the distribution of sand body.

The tectonic framework in the southwest area of Qaidam in Paleogene is bounded on the Aral and Kunbei fault, formed the Qigequan - Hongliuquan - Yaojin(fault fall plate, Aral), Tiemulike (fault rising plate, Aral) and Kunbei - Wunan three ancient slope belts, and negative tectonic units are mainly Yingxiongling and Zhahaquan two big sags ${ }^{[28]}$. By the research, the three ancient slopes in the southwest of Chaidam also develop tectonic slope-break belt in Paleogene ${ }^{[29-30]}$, and the sand body is superimposed continuous accumulation zones. By seismic and geological data comprehensive recognition, combined with the ancient tectonic evolution characteristics (figure 2), the study area developed Qigequan, Hongliuquan, Aral, Kunbei and XI five large fracture slope break belts. The 5 fracture slope break belts and the rise and fall of the relative lake level control the sedimentary filling of the whole of the southwest area, also control the distribution of sand body.

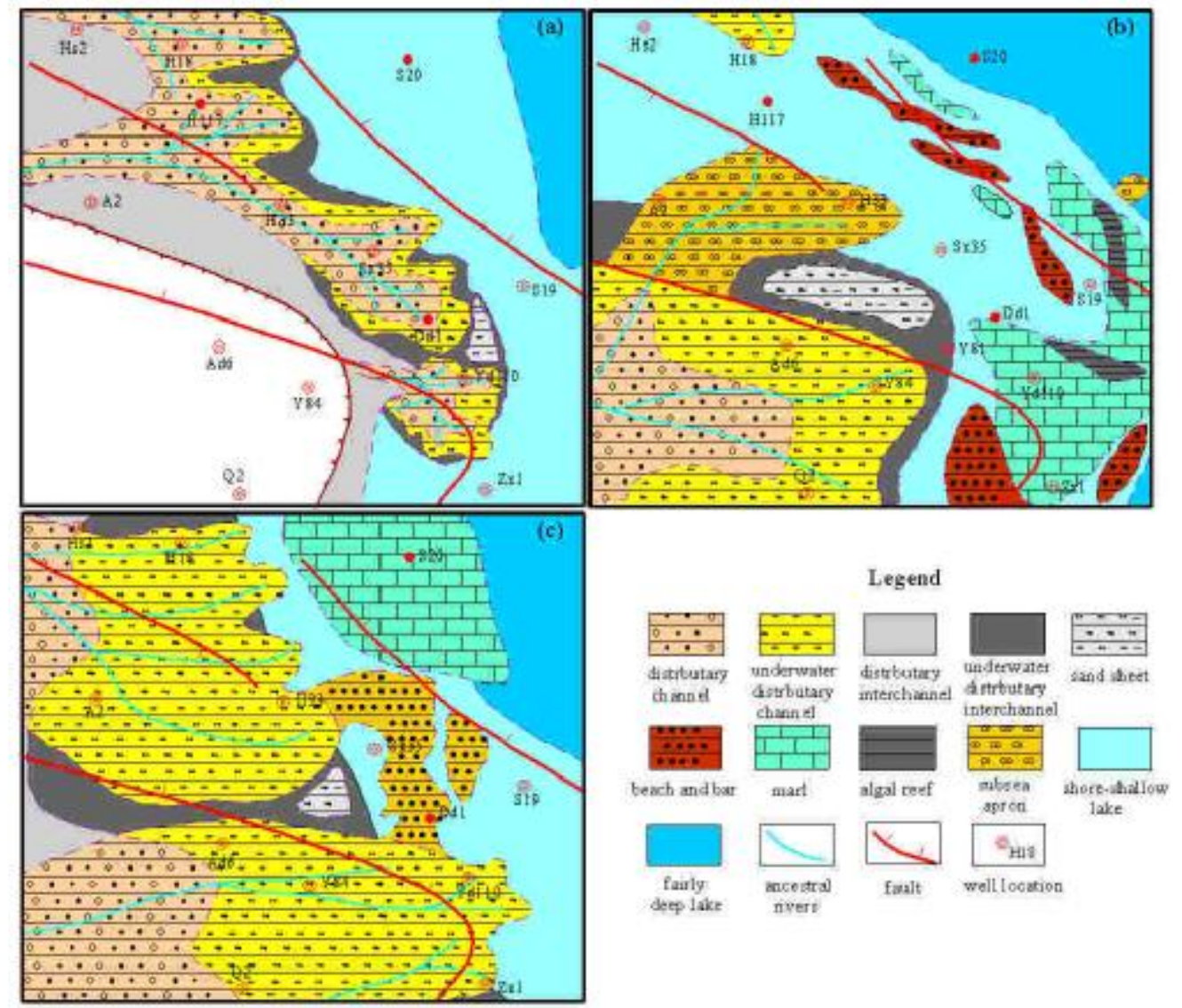

\section{(a) $\mathrm{E}_{3}{ }^{1}$; (b) $\mathrm{E}_{3}{ }^{2}$; (c) $\mathrm{N}_{1}$}

Fig. 5 Distribution of Paleogene sedimentary facies in southwestern Qaidam Basin

According to the relationship of the provenance supply direction and fracture slope break belt tendency, the fracture slope break belt can be divided into inverse source type and along the source two kinds, the tendency of reverse source type fracture slope break belt and provenance supply in the same direction, downthrown side can form a certain scale of small fault trough, sand body along the fault to the article roughly zonal distribution (figure 6 (a)), the tendency and the provenance supply of along the source is in the opposite direction. The downthrown side along provenance direction can provide sand accumulation space (figure 6 (b) and figure 7). On one side of the fracture slope break belt, next to Altun Mountains in the southwest of Chaidam, the tendency is east 
to the north, such as Qigequan and Hongliuquan fracture slope break belt, with the same direction of the Aral source, belongs to the inverse source type fracture slope break belt. Near the Kunlun mountains, on the other hand, the fracture slope break belt and XI fracture slope break belt and its tendency is southwest, Tiemukeli and Qimantage source are in the opposite direction, belongs to along the source fracture slope break belt (figure 7). At the same time, due to the fracture is mainly from the north and the south up extrusion stress and the formation of the thrust faults, the upper and lower plate of the fault are easily formed low amplitude palaeohigh under the influence of extrusion stress $^{[29]}$, result in the production of flexure slope break zone in the overlying strata, such as XI fault up plate in lower Ganchaigou formation $\left(\mathrm{E}_{3}{ }^{2}\right)$ along the fault strike the sedimentation developing algal reef and beach dam (figure 5, figure 6 (b) (a) and 6 (b)). Fracture slope break and flexure slope break zones are collectively referred to as structural slope break belt, which is the southwest region of the control in one of the most important factors of the distribution of sand body.
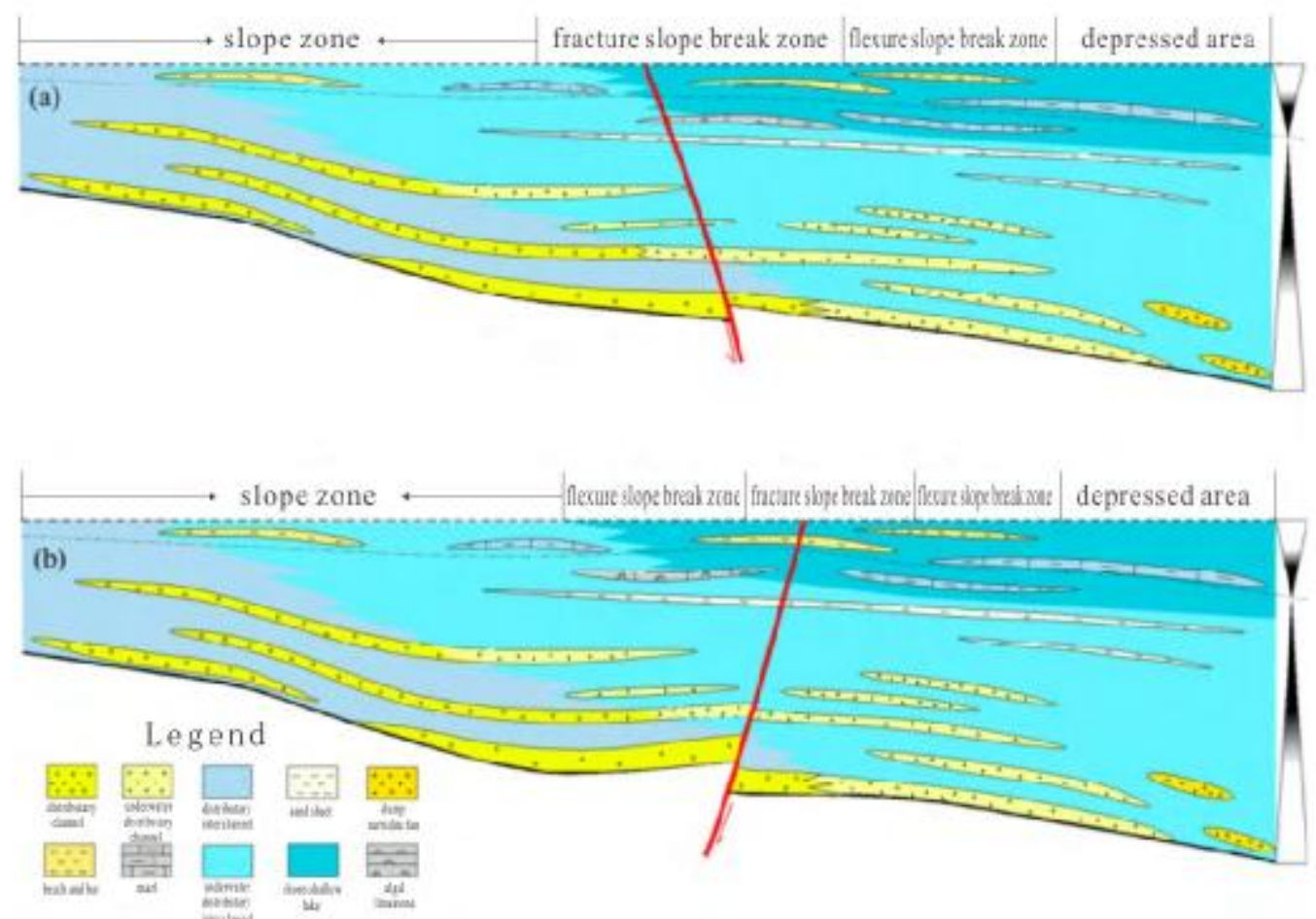

(a) inverse source of slope break; (b) follow source of slope break

Fig. 6 Pattern of fracture slope-break zone controling sandstones section in southwestern Qaidam Basin $\left(\mathrm{E}_{3}{ }^{1}\right)$ 


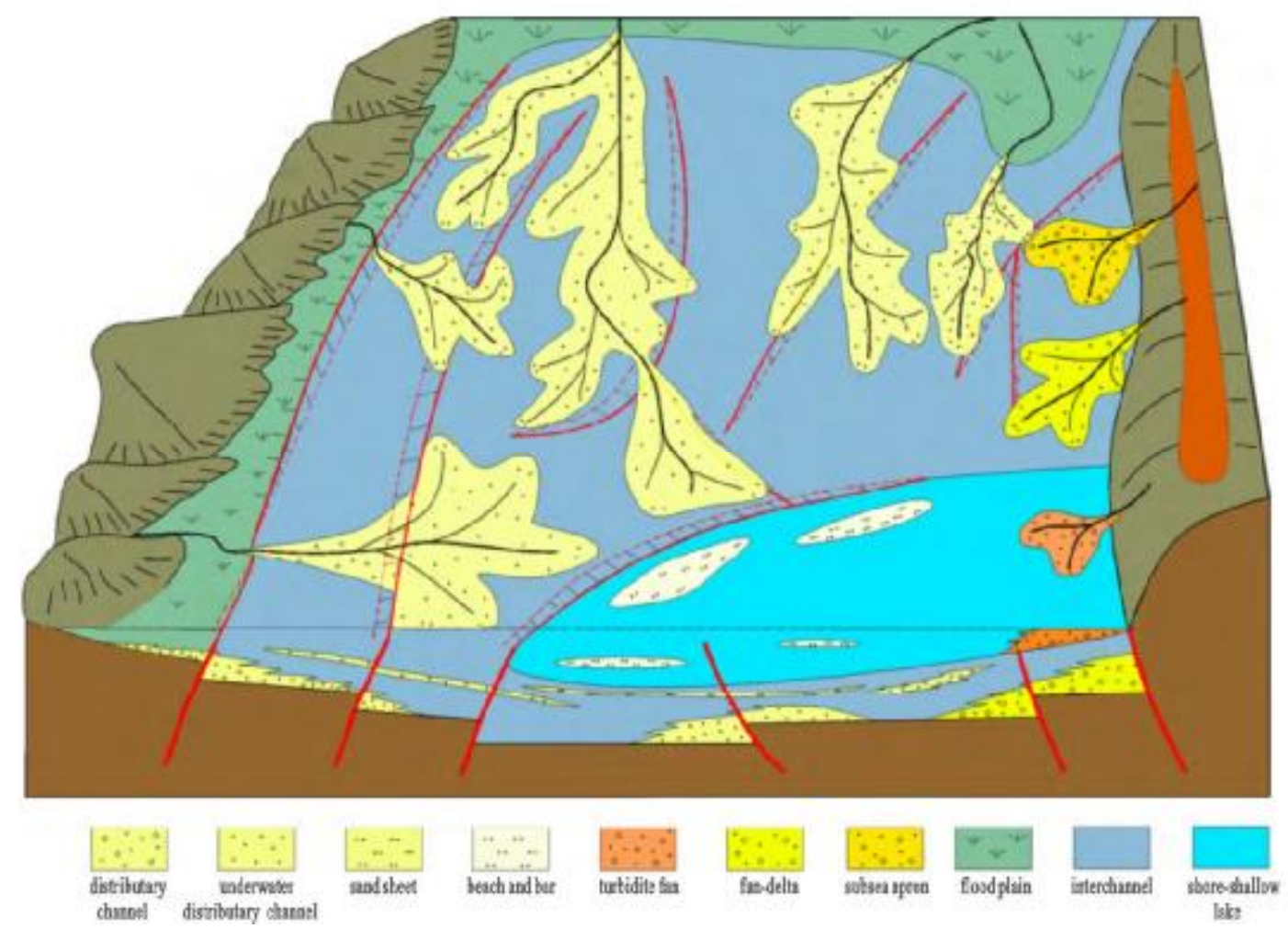

Fig. 7 Model of fracture slope-break zone controlling sandstones in southwestern Qaidam Basin At present, the lithologic oil and gas exploration in the Qaidam southwest area is mainly concentrated in the upthrown side of fracture slope break belt, such as Hongliuquan oilfield, Qigequan oilfield, Kunbei oil field, etc., mainly for underwater distributary channel sand bodies of braided river delta front updip lithologic reservoirs, as a matter of fact, according to the slope break belt sand control mechanism, below the fracture slope break belt with the more depositional cycle, more layers and more thick sandstone, and reservoir nearer provenance, extremely easy to form a beach bar sand body and turbidite fan sand bodies as the main body of sandstone lens, lithologic hydrocarbon reservoirs, such as under theXI fracture, delta front along with the deepening of water into shore and shallow lake, developing comparable size beach bar sand body and turbidite fan sand bodies (figure 7), which are the main "undercut looking for oil" lithologic targets.

\section{Conclusion}

In Paleogene, the southwest area of Qaidam, the overall structure is relatively flat, forming "basin wide shallow lake" ancient terrain, with the paleostructural basis of forming large shallow water delta; At the same time, the climate is arid or semi-arid environment, conducive to intense physical weathering of source rock, providing a rich material foundation for the formation of a large shallow water delta; And the ancient water depth under 10m, lake level changed quite frequently, water turbulence back and forth, fully reflects the characteristics of shallow water sedimentary environment.

In the study area, the main lithology of shallow water delta facies is medium - fine sandstone, siltstone, conglomerate and gravel sandstone with palm red mudstone, grain size probability curve presents the characteristics of the two stages, with rich sedimentary structure and biological trace fossils reflecting the strong hydrodynamic formation.

Considering the climate change, the relative lake level change and provenance supply, we think that 
the shape of shallow water delta sand body in Qaidam southwest area in Paleogene according to the degree of sheet can be divided into branches, lump and sheet three kinds, roughly corresponding to the lower segment of Ganchaigou formation, the upper segment of Ganchaigou formation and upper Ganchaigou formation sand body characteristics.

4) The study area in Paleogene developed fracture slope break belt, Qigequan, Hongliuquan, Aral, Kunbei and XI, this article 5 fracture slope break belt and its derived from the rise and fall of flexure slope break belt and relative lake level control the sedimentary filling of the whole of the southwest area, also control the distribution of sand body.

5) According to the relationship between provenance supply direction and fracture slope break belt tendency, the fracture slope break belt can be divided into inverse source type and along source two kinds, the tendency of reverse source type fracture slope break belt and provenance supply in the same direction, downthrown side can form a certain scale of small fault trough, sand body along the fault to roughly a zonal distribution, along source shaped fracture slope break belt and provenance supply in the opposite direction, the down platefall following the provenance direction can provide sand accumulation space, and on this basis to establish structural slope break zones sand control mode in Chaidam southwest area Paleogene, and provide guidance for lithologic reservoir exploration direction.

\section{References}

[1] Postma G. An analysis of the variation in delta architecture[J]. Terra Nova, 1990, 2(2): 124-130.

[2] Lemons D R, Chan M A. Facies architecture and sequence stratigraphy of fine-grained lacustrine deltas along the eastern margin of late Pleistocene Lake Bonneville, northern Utah and southern Idaho[J]. AAPG Bulletin, 1999, 83(4): 635-665.

[3] Fisk H N, Kolb C R, Mcfarlan E, et al. Sedimentary framework of the modern Mississippi delta [Louisiana][J]. Journal of Sedimentary Research, 1954, 24(2): 76-99.

[4] Donaldson A C. Pennsylvanian sedimentation of central appalachians[J]. Geological Society of America Special Paper, 1974, 148(2): 47-78.

[5] Baofeng Zhao, Jiahao Wang, Donghao Xu, et al. Semi-quantitative research on subaqueous distributary channel sandbodies of the 3rd member of Nenjiang Formation in Xinli-Xinbei Area, Songliao Basin[J]. Acta Sedimentologica Sinica, 2012, 30(3): 511-521. (In Chinese)

[6] Zhanghua Lou, Qingmei Lu, Xiyuan Cai, et al. Influence of lake level fluctuation on sandbody shapes at shallow-water delta front[J]. Acta Sedimentologica Sinica, 1998, 16(4): 27-31. (In Chinese)

[7] Xiaomin Zhu, Rong Pang, Dongna Zhong, et al. Formation and development of shallow-water deltas in lacustrine basin and typical case analyses[J]. Journal of China University of Petroleum (Science and Technology), 2013, 37(5): 7-14. (In Chinese)

[8] Zhangdong Li, Shuangfang Lu, Junhui Li, et al. Sedimentary characteristics and evolution of member 1 of Yaojia Formation of cretaceous in Zhaoyuan - Taipingchuan area of Songliao Basin[J]. Journal of Central South University (Science and Technology), 2011, 42(12): 3818-3826. (In Chinese)

[9] Wuxian Shen, Tailiang Fan, Gang Guo, et al. Development of reservoir sandbody in sequence stratigraphic framework of middle-lower Jurassic in Turpan Sag[J]. Journal of Central South University (Science and Technology), 2009.40(6): 1672-1678. (In Chinese)

[10] Guangqing Yao, Zheng Ma, Yanchao Zhao, et al. Reservoir characteristics of distributary channel sand bodies of shallow water delta[J]. Acta Petrolei Sinica, 1995, 16(1): 24-31. (In 
Chinese)

[11] Caineng Zou, Wenzhi Zhao, Xingyang Zhang, et al. Formation and distribution of shallow-water deltas and central-basin sandbodies in large open depression lake basins[J]. Acta Geologica Sinica, 2008, 82(6): 813-825. (In Chinese)

[12] Xiaomin Zhu, Yuan Liu, Qing Fang, et al. Formation and sedimentary model of shallow delta in large-scale lake: Example from Cretaceous Quantou Formation in Sanzhao Sag, Songliao Basin[J]. Earth Science Frontiers, 2012, 19(1): 89-99. (In Chinese)

[13] Yuanhao Li, Chiyang Liu, Yuguo Du, et al. Sedimentary characteristics of shallow water delta and lake shoreline control on sandbodies of Chang 8 oil-bearing interval of the Upper Triassic Yanchang Formation in northwestern Ordos Basin[J]. Journal of Palaeogeography, 2009, 11(3): 265-274. (In Chinese)

[14] Weilin Zhu, Jianping Li, Xinhuai Zhou, et al. Neogene shallow water deltaic system and large hydrocarbon accumulations in Bohai Bay, China[J]. Acta Sedimentologica Sinica, 2008, 26(4): 575-582. (In Chinese)

[15] Wei Zhao, Longwei Qiu, Zaixing Jiang, et al. Depositional evolution and model of shallow-water delta in the rifting lacustrine basins during the shrinking stage: A case study of the third member and second member of Paleogene Shahejie formation in the Niuzhuang subsag, Dongying Sag[J]. Acta Geologica Sinica, 2011, 85(6): 1019-1027. (In Chinese)

[16] Liuhong Liu, Rukai Zhu, Ping Luo, et al. Characteristics and depositional models for the shallow-water deltas of the 5th-6th interval, Xujiahe formation, upper Triassic in central Sichuan Basin, China[J]. Geoscience, 2009, 23(4): 667-675. (In Chinese)

[17] Guoqiang Cao. Sedimentary facies of the Tertiary in west Qaidam Basin[D]. Guangzhou: Chinese Academy of Sciences. Guangzhou Institute of Geochemistry, 2005: 108-120. (In Chinese)

[18] Changmin Zhang, Taiju Yin, Yongjing Zhu, et al. Shallow-water deltas and models[J]. Acta Sedimentologica Sinica, 2010, 28(5): 933-944. (In Chinese)

[19] Shiyuan Li, Yadong Wang, Yuezhong Zhang, et al. Cenozoic evolution of dominating faults in western Qaidam and its implication[J]. Chinese Journal of Geology, 2010, 45(3):666-680. (In Chinese)

[20] Lanbing Li, Lina Sun, Jiazhen Sun, et al. The fracture characteristic analysis in Southwest area of Qaidam Basin[J]. Oil Geophysical Prospecting, 2010, 45(3): 443-447. (In Chinese)

[21] Lei Wu. The Cenozoic tectonic process of central segment of the Altyn Tagh fault and its Basin response[D]. Hangzhou: Zhejiang University. Department of Earth Sciences, 2011: 110-122. (In Chinese)

[22] Ya Shen, Hongge Li, Junya Guang, et al. Structure features and exploration potential of the Paleogene-Neogene depressions in Western Qaidam Basin[J]. Oil Geophysical Prospecting, 2012, 47(Supplement1): 111-117. (In Chinese)

[23] Zhenhan Wu, Xun Zhao, Peisheng Ye, et al. Paleo-Elevation of the Tibetan Plateau inferred from carbon and oxygen isotopes of lacustrine deposits[J]. Acta Geologica Sinica, 2007, 81(9): 1277-1288. (In Chinese)

[24] Zeqing Guo, Dewen Zhen, Weihong Liu, et al. Discovery and significance of the Neogene and Palaeogene lacustrine reefs in the western Qidam Basin[J]. Journal of Stratigraphy, 2008, 32(1): 60-68. (In Chinese)

[25] Ping Yang. Study on Tertiary sequence biostratigraphy in Qigequan - Hongliuquan region, western Qaidam Basin[D]. Beijing: China University of Geosciences (Beijing). School of Energy Resources, 2007: 15-16. (In Chinese) 
[26] Xin Su, Xuan Ding, Zaixing Jiang, et al. Using of multi-microfossil proxies for reconstructing quantitative paleo-water depth during the deposit period of LST of Es ${ }^{4 \mathrm{~s}}$ in Dongying Depression[J]. Earth Science Frontiers. 2012, 19(1): 188-199. (In Chinese)

[27] Xiangfeng Wu. Lake level fluctuation pattern and controlling factors of Shangganchaigou Formation and Xiaganchaigou Formation, western Qaidam Basin[D]. Chengdu: Chengdu University of Technology. School of Energy Resources, 2010: 59-70. (In Chinese)

[28] Xiaobao Zhang, Zhongwei Ping, Daowei Zhang, et al. Formation conditions of structural lithological oil and gas reservoirs and exploratory prospects in the southwest of the Qaidam Basin, China[J]. Natural Gas Geoscience, 2011, 2(2): 240-249. (In Chinese)

[29] Yajun Shi, Zhenlin Cao, Xiaojun Zhang, et al. Characteristics of hydrocarbon enrichment in lithologic reservoirs in the southwestern Qaidam Basin[J]. Natural Gas Industry, 2009, 29(2): 37-41. (In Chinese)

[30] Xiujian Sun, Yingru Liu, Xingfu Le, et al. Main controlling factors of lithologic reservoirs in Hongliuquan area, Qaidam Basin[J]. Natural Gas Geoscience, 2010, 21(5): 801-808.(In Chinese) 